\title{
FORUM
}

\section{The need for a hydromorphological approach to Chilean river management}

\author{
La necesidad de un enfoque hidromorfológico para la gestión de los ríos chilenos
}

\section{ANDREA ANDREOLI ${ }^{1,}{ }^{*}$, LUCA MAO ${ }^{2}$, ANDRÉS IROUMÉ ${ }^{3}$, JOSE L. ARUMÍ ${ }^{4}$, ANDREA NARDINI $^{5}$, ROBERTO $^{2}$ PIZARRO $^{6}$, DIEGO CAAMAÑO ${ }^{7}$, CLAUDIO MEIER $^{8} \&$ OSCAR LINK $^{8}$}

\author{
${ }^{1}$ Universidad de Concepción, Department of Forestry and Environmental Management, Victoria 631, 4070374 Concepción, \\ Chile
}

2Pontificia Universidad Católica de Chile, Department of Ecosystems and Environments, Av. Vicuña Mackenna 4860, 7820436

Macul, Casilla 306-22, Santiago, Chile

${ }^{3}$ Universidad Austral de Chile, Institute of Forest Management, Independencia 641, 5110566 Valdivia, Chile

${ }^{4}$ Universidad de Concepción, Department of Water Resources, Vicente Méndez 595, 3801061 Chillán, Chile

${ }^{5}$ Centro Italiano per la Riqualificazione Fluviale (CIRF), International Research and Cooperation section, Viale Garibaldi 44/A, 30173 Mestre (Venezia), Italy

${ }^{6}$ Universidad de Talca, Hydrology and Environment Technology Center, Dos Norte 685, 3465548 Talca, Chile

${ }^{7}$ Universidad Católica de la Santísima Concepción, Department of Civil Engineering, Alonso de Ribera 2850, 4090541

Concepción, Chile

${ }^{8}$ Universidad de Concepción, Department of Civil Engineering, Edmundo Larenas 270, 4070409 Concepción, Chile

${ }^{*}$ Corresponding author: aandreoli@udec.cl

\begin{abstract}
The manuscript reflects the opinion of the authors about the need for a hydromorphological approach for the management of Chilean rivers. A brief state-of-the-art of the recent scientific advances on hydromorphological approach to river management is presented, as well as a general overview of the conditions of Chilean rivers and the mayor disturbances they suffer. Moreover, the need to take into account both direct and indirect services provided by rivers in the decision making process on river management is underlined. Hydromorphology is claimed to be a main element to be considered while assessing the ecological state of rivers. Understanding how the hydrological and morphological variables interact dynamically is indeed key to assess the presence or absence of dynamic equilibrium, a condition that, in turn, promotes both habitat diversity and self-sustainable aquatic and riparian ecosystems. The authors also emphasized the need for a change of paradigm in current Chilean rivers management practices, by developing a unified framework to assess hydromorphological and ecological river conditions. In addition, the implementation of specific legislation aimed at promoting ecological and geomorphological standards in river management practice, and the strengthening and widening of the academic teaching of fluvial ecology and geomorphology is suggested.
\end{abstract}

Key words: Chile, fluvial ecology, fluvial geomorphology, management, rivers.

\section{RESUMEN}

El manuscrito refleja la opinión de los autores acerca de la necesidad de aplicar un enfoque hidromorfológico para la gestión de los ríos chilenos. Se presenta una breve reseña de los últimos avances científicos sobre el enfoque hidromorfológico en la gestión de ríos, así como una visión general de las condiciones de los ríos chilenos y sus mayores perturbaciones. Por otra parte, se hace énfasis en la necesidad de incluir en la toma de decisiones los servicios directos como los indirectos proporcionados por los ríos. Se afirma que la hidromorfología es un elemento fundamental a considerar al determinar el estado ecológico de los ríos. La comprensión de cómo las variables hidrológicas y morfológicas interactúan de forma dinámica es sin duda clave para evaluar la presencia o ausencia de un equilibrio dinámico, una condición que, a su vez, fomenta tanto la diversidad de hábitat como el desarrollo sostenible de los ecosistemas acuáticos y ribereños. Los autores concluyen que es necesario cambiar el paradigma actual de gestión aplicado en los ríos chilenos desarrollando una estrategia que permita evaluar las condiciones hidromorfológicas y ecológicas de los ríos. Además, sugieren implementar legislación específica orientada a promover estándares ecológicos y geomorfológicos en la práctica de gestión, con el apoyo de un fortalecimiento y una ampliación de la enseñanza académica de la geomorfología y ecología fluvial.

Palabras clave: Chile, ecología fluvial, geomorfología fluvial, gestión, ríos. 


\section{THE RELEVANCE AND MULTIPLE SERVICES OF RIVER SYSTEMS}

River systems convey as streamflow the precipitation collected in their watersheds. As such, rivers are the final expression of a wide range of geological, geomorphological, hydro-meteorological, ecological and biological processes acting at a variety of spatial and temporal scales over their drainage basins.

Rivers and their closely associated floodplains represent corridors of extraordinary ecological, environmental, social, cultural, and economic value. Far from being mere water conveyers, streams and rivers are complex ecosystems where the three-dimensional interaction of streamflow, geological substratum, relief, sediments, dead wood, and vegetation creates a heterogeneous array of ever-changing fluvial forms, which provide a shifting mosaic of habitat patches for aquatic and riparian organisms (Stanford et al. 2005). For example, the variable velocity, depth and turbulence maintain diverse substrates, thermal refugia, and hydraulic conditions that are essential for the various life-stages of aquatic biota (Jowett 1993).

At the same time, rivers supply humans with a set of resources and services such as water for domestic, agricultural, hydropower and industrial use, mining of sand and gravel, waterways for navigation, fishing, waste disposal, as well as recreational and aesthetic uses. Furthermore, rivers represent a fundamental source of cultural and social values for riverine communities. Degradation of these ecosystems has been so severe that massive investments in wastewater treatment and river restoration are now needed in many countries worldwide (Bernhardt et al. 2005, Palmer et al. 2005). For these reasons, it is imperative to ensure sustainability of river management strategies by means of systemic and integrated decision-making policies (i.e. EU Water Framework Directive, 2000/60).

It is known that rivers adjust their local forms and processes depending on ranges of available water and sediment (Leopold et al. 1964). Thus fluvial systems are sensitive to changes on magnitude, frequency and/ or location of these two sources, and respond to a continuous feedback that seek a state of dynamic equilibrium (i.e. equivalent rates of erosion and deposition at various spatial and temporal scales). Increases in human population and industrial, commercial, and residential development certainly results in heavy impacts on the amount of water and sediment available at different scales within the fluvial system. This, affect the river morphological and ecological regimes since the previous balance conditions are rearranged to fit new scenario. Despite these changes, and up to a few decades ago, the main indicators for assessing the quality of fluvial freshwater ecosystems were limited to water chemistry (mostly nutrients) and living organisms. Slowly, hydro-ecological indicators referring to minimum or ecological discharge and hydropeaking were implemented in order to assess the quality of river systems affected by human disturbances (e.g., hydropower generation and flow diversions) and recently, and especially due to the considerable impulse given by the European Water Framework Directive (EU 2000), hydromorphology has been introduced as one of the main elements to be evaluated, besides water quality and biological aspects, in order to assess the ecological state of river systems.

This recent focus on hydromorphology derives from the fact that several investigation have proven that providing natural hydrological and sedimentological regimes, river processes will, at some point, operate in a state of dynamic equilibrium and thus promote habitat diversity and sustainable functioning of aquatic and riparian ecosystems (e.g., Palmer et al. 2005).

\section{FLUVIAL GEOMORPHOLOGY AND HYDRO-MOR- PHOLOGY}

Fluvial geomorphology has been defined as the study of sediment sources, fluxes and storage within the river catchment and channel over short, medium and longer time scales and of the resultant channel and floodplain morphology (Newson \& Sear 1993). More broadly, it examines and predicts the forms and processes that operate in river systems and the landforms that they create. Understanding the geomorphology of a fluvial system is therefore vital to the understanding of both the current processes and dynamics of rivers and how they may respond to future changes. 
Despite the intuitive direct relationship between the diversity of fluvial forms and the availability of ecological niches for aquatic and riparian species, discovering the links between river hydrology, morphology and ecology is still a challenge, especially at the quantitative levels required for effective prediction and management. However, a novel interdisciplinary field alternative mainly called eco-hydro-morphology (Newson 2002, Vaughan et al. 2009) has recently emerged in order to fill this gap and improve the understanding of the relationships between organisms and physical habitats in rivers. At the moment there are only a few methods and approaches available to assess the eco-morphological values of river systems, among which it is worth mentioning the "River Habitat Survey" in the UK (Raven et al. 1998), the "Hidromorphologic Evaluation Index” in Spain (Ollero et al. 2008), the "Relational System of Hydromorphology Watercourse Audit" in France (Chandesris et al. 2008) and the "Hydromorphological Assessment System" in Italy (Rinaldi et al. 2011). These methods differ because of the distinct perspectives from which they were shaped, the special nature of rivers, and specific human impacts in the countries where they were developed.

\section{THE CONDITIONS OF CHILEAN RIVERS}

Draining one of the highest and longer mountain ranges in the world as a response to extremely variable meteorological regimes from North to South (i.e. from the Atacama Desert to Patagonia) and from East to West (i.e. from Andean Cordillera to the coast), Chilean rivers exhibit a tremendous hydrological and morphological diversity. For example there are single-thread mountain rivers with steppool sequences in the upper mountainous regions, braided reaches in the lower piedmont courses, meandering rivers in the Cordilleran hanging valleys (i.e. tributary valleys whose mouth lies at a higher elevation than the main channel into which they flows), and also ephemeral streams in the northern regions. This morphological diversity is one of the most precious characters of Chilean rivers, and results from the particularly wide range of climatic and physiographic conditions along the country.
Despite a relatively short history of heavy river intervention, many Chilean rivers now suffer from different ranges and intensities of human disturbances that have altered their morphology and dynamics. Activities undertaken within the river corridor, such as channelization, over-extraction of river flows for irrigation or run-of-the-river hydropower generation, damming, and gravel mining, directly alter channel geometry, the dynamics of water and sediment fluxes, and aquatic/ riparian communities. Rivers are also affected by indirect activities undertaken at the basin scale such as introduction of exotic species or changes in land-use (e.g., extensive deforestation and urbanization), and/ or seasonal alterations such as wildfires.

Despite these widespread anthropogenic disturbances, scientific evidence of human impacts on fluvial and riparian environments is scarce and only available locally. It is especially lacking for rivers draining the arid and semiarid areas of the country. For example, Mancilla et al. (2009) reported on the effects of native riparian vegetation removal on structure and composition of the aquatic community in the Biobío Region. Little et al. (2009) showed how forest cover and land-use changes could alter the hydrological regime of Mediterraneanclimate basins of South-Central Chile. More information is available about the impacts on fish communities. For example, Orrego et al. (2009) found that the structure of fish communities is highly influenced by human disturbance along the lower reaches of the Chillán river, Habit et al. (2006) related the reduction in distribution of native fish species to large-scale and long-term effects of recent human impacts on the Biobío River, and García et al. (2010) showed that fish habitat quality changes due to dam operation and daily hydropeaking. Also, Stehr et al. (2010) modeled the hydrologic response of a mesoscale Andean watershed to changes in land use patterns for environmental planning, and Ponce et al. (2011) evaluated the economic value of landscape losses due to flooding by hydropower plants in the Chilean Patagonia.

Overall, even when limited, current evidence suggests that Chilean rivers will be progressively threatened by excessive impacts that will further reduce water quality, hydrological variability and morphological 
equilibrium, resulting in turn in a reduction of river biological and ecological values. Putting it into perspective, it is evident that current Chilean fast-growing economy produces a conflict between the need to use river resources and the wishes of maintaining rivers in near-natural conditions. A sustainable river management strategy should find a trade-off between the direct services provided by a river (e.g., irrigation, hydropower, domestic supply) and those indirect services that it would supply if not overexploited (e.g., fishing and landscape, touristic and recreational activities, nature and resource conservation), and combine them with the local socio-economic setting.

Not meeting sustainable management goals for Chilean rivers could results in future problems. In fact, experiences from developed countries are quite clear in showing that impacted rivers cause long-term costs that are much higher than the immediate value of the exploited resources. For example, Bernhardt et al. (2005) report that at least 14 to 15 billion US dollars were spent in river restoration activities in the United States from 1990 to 2003, at an average of over 1 billion dollars per year. They also report that this is an underestimation of the true figure.

Moreover, Chilean watersheds are regularly affected by severe disturbances such as volcanic eruptions, wildfires, earthquakes, landslides, debris flows, extreme droughts and extreme floods. When such events occur, they can substantially modify hydrologic and geomorphic patterns and processes over watersheds, killing or burying large amounts of vegetation, adding large volumes of highly erodible sediment or wood that can divert or dam stream channels, and disrupting normal hydrologic pathways. To date, such effects have been little studied, and the vulnerability of these watersheds to the spectrum of disturbance processes, as well as their hydrologic and geomorphic responses are not well understood.

\section{JUST ABOUT THE RIGHT TIME FOR DEVELOPING HYDROMORPHOLOGICAL STUDIES IN CHILE}

From all the above, it appears that current Chilean river management practices need a change of paradigm in order to be sustainable. Within this context, the first need would be to develop a framework for assessing river conditions, considering their hydromorphological and ecological properties, and not only water quality, as has been done up to now. Considering the state-of-the-art, existing hydromorphological studies and approaches, developed elsewhere, should be adapted to the local reality in order to develop protocols and procedures to appraise the status of Chilean rivers, to prioritize listings for river conservation and restoration, and above all, to guide sustainable river management strategies even just to greatly improve the output of many small, widely spread engineering projects of river management that today suffer from a limited geomorphological perspective. To achieve this, it would be first necessary to study in detail the morphology of Chilean rivers, characterize their types and survey river hydromorphological characteristics with a standardized methodology resulting in a specific framework of survey procedure and checklist. The protocol would necessarily have to consider the wider range of river morphologies and also the particular nature of human disturbances (e.g., water diversions, river damming, gravel mining, urbanization, forestry activities) and their distribution along the country.

River geomorphological research hasn't received much attention in Chile until very recently, when numerous national and international projects started focusing on fluvial form, processes and dynamics as a tool to develop sustainable river management strategies. More studies of such kind would be definitely welcome in order to increase the knowledge of Chilean river systems. Beside, specific legislation requiring hydromorphological assessment of rivers impacted by human interventions (e.g., gravel mining, channel rectifications, water diversions) should be implemented. Finally, it would be necessary to increase ecological and geomorphological standards in river management practice. This could be achieved by strengthening and widening the teaching of fluvial ecology and geomorphology to students engaged in a wide range of disciplines such as civil, forest, agricultural, environmental and natural resources engineering, biology, geology and geography. 
ACKNOWLEDGMENTS: The authors thank the two anonymous referees for their comments and suggestions. This work was supported by the following FONDECYT projects: n.1090774 (A. Andreoli and L. Mao), n.1110609 (A. Iroumé), n.1110298 (J.L. Arumí), n.11100399 (D. Caamaño), n.11080163 (C. Meier) n.1120897 (O. Link), FONDEF project DO8I1054 (R. Pizarro), and UE FP7 IRSES-PEOPLE project SERELAREFA (A. Nardini).

\section{LITERATURE CITED}

BERNHARDT ES, MA PALMER, JD ALLAN, G ALEXANDER, K BARNAS et al. (2005) Synthesizing U.S. River Restoration Efforts. Science 308: 636-637.

CHANDESRIS A, N MENGIN, JR MALAVOI, Y SOUCHON, H PELLA \& JG WASSON (2008) Système relationnel d'audit de l'hydromorphologie des cours d'eau: Principes et méthodes. Cemagref, Lyon, France.

GARCÍA A, K JORDE, E HABIT, D CAAMAÑO \& O PARRA (2010) Downstream environmental effects of dam operations: Changes in habitat quality for native fish species. River Research and Applications 27: 312-327.

HABIT E, B DYER \& I VILA (2006) Estado de conocimiento de los peces dulceacuícolas de Chile. Gayana 70: 100-113.

JOWETT IG (1993) A method for objectively identifying pool, run, and riffle habitats from physical measurements. New Zealand Journal of Marine and Freshwater Research 27: 241-248.

LEOPOLD LB, MG WOLMAN \& JP MILLER (1964) Fluvial processes in geomorphology. W.H. Freeman and Company, New York.

LITTLE C, A LARA, J MCPHEE \& R URRUTIA (2009) Revealing the impact of forest exotic plantations on water yield in large scale watersheds in SouthCentral Chile. Journal of Hydrology 374: 162-170.

MANCILLA G, C VALDOVINOS, M AZOCAR, P JORQUERA \& R FIGUEROA (2009) Efecto del reemplazo de la vegetación nativa de ribera sobre la comunidad de macroinvertebrados bentónicos en arroyos de climas templados, Chile central. Hidrobiológica 19: 193-203.

NEWSON MD (2002) Geomorphological concepts and tools for sustainable river ecosystem management. Aquatic Conservation: Marine and Freshwater Ecosystems 12: 365-379.

Editorial responsibility: Julio R. Gutiérrez

Received March 6, 2012; accepted September 24, 2012
NEWSON MD \& DA SEAR (1993) River conservation, river dynamics, river maintenance: Contradictions? In: White S, Green J \& MG Macklin (ed) Conserving our landscape. Joint Nature Conservancy, Peterborough, England.

OLLERO A, D BALLARIN, E DÍAZ, D MORA, M SANCHEZ et al. (2008) IHG: Un indice para la valoracion hidrogeomorfologica de sistemas fluviales. Limnetica 27: 171-188.

ORREGO R, S MARSHALL ADAMS, R BARRA, G CHIANG \& J GAVILÁN (2009) Patterns of fish community composition along a river affected by agricultural and urban disturbance in southcentral Chile. Hydrobiologia 620: 35-46.

PALMER MA, ES BERNHARDT, JD ALLAN, PS LAKE, G ALEXANDER et al. (2005) Standards for ecologically successful river restoration. Journal of Applied Ecology 42: 208-217.

PONCE R, F VÁSQUEZ, A STEHR, P DEBELS \& C ORIHUELA (2011) Estimating the economic value of landscape losses due to flooding by hydropower plants in the Chilean Patagonia. Water Resources Management 25: 2449-2466.

RAVEN PJ, NTH HOLMES, FH DAWSON \& M EVERARD (1998) Quality assessment using river habitat survey data. Aquatic Conservation: Marine and Freshwater Ecosystems 8: 477-499.

RINALDI M, N SURIAN, F COMITI \& M BUSSETTINI (2011) Guidebook for the evaluation of stream morphological conditions by the Morphological Quality Index (IQM). Istituto Superiore per la Protezione e la Ricerca Ambientale, Rome, Italy.

STANFORD JA, MS LORANG \& FR HAUER (2005) The shifting habitat mosaic of river ecosystems. Internationalen Vereinigung $\mathrm{f} r$ Theoretische und Angewandte Limnologie Verhandlungen (Stuttgart, Germany) 29: 123-136.

STEHR A, M AGUAYO, O LINK, O PARRA, F ROMERO \& H ALCAYAGA (2010) Modelling the hydrologic response of a mesoscale Andean watershed to changes in land use patterns for environmental planning. Hydrology and Earth System Sciences 14: 1963-1977.

VAUGHAN IP, M DIAMOND, AM GURNELL, KA HALL, A JENKINS, et al. (2009) Integrating ecology with hydromorphology: A priority for river science and management. Aquatic Conservation: Marine and Freshwater Ecosystems 19: 113-125. 
